\title{
In Vitro Antioxidant and Anticancer Activity of Flavonoid Fraction from the Aerial Parts of Cissus quadrangularis Linn. against Human Breast Carcinoma Cell Lines
}

\author{
A. Vijayalakshmi, P. R. Kumar, S. Sakthi Priyadarsini, and C. Meenaxshi \\ Department of Pharmacognosy, College of Pharmacy, SRM University, Kattankulathur, Tamil Nadu 603203, India \\ Correspondence should be addressed to A. Vijayalakshmi; aviji_1975@rediffmail.com
}

Received 29 May 2013; Accepted 9 July 2013

Academic Editor: Filomena Conforti

Copyright (C) 2013 A. Vijayalakshmi et al. This is an open access article distributed under the Creative Commons Attribution License, which permits unrestricted use, distribution, and reproduction in any medium, provided the original work is properly cited.

\begin{abstract}
Aim. The present study aimed to isolate flavonoid fraction from the aerial parts of Cissus quadrangularis and to evaluate its antioxidant and anticancer potential using in vitro assay system. Methods. Total phenolic and flavonoid contents were calculated for the drug. Flavonoid fraction was isolated using column chromatography and analysed using HPLC. In vitro, antioxidant activity of the ethanol extract and isolated flavonoid fraction was investigated by nitric oxide, DPPH and hydroxyl radical scavenging assays. Breast cancer (MCF 7) cell line was used as the in vitro cancer model for MTT assay. Result. The amount of total phenolic content and total flavonoid content in the ethanol extract showed $28.6 \mathrm{mg} / \mathrm{g}$ dry weight expressed as gallic acid equivalents, and $15.8 \mathrm{mg} / \mathrm{g}$ was expressed as quercetin equivalents, respectively. The tested extract showed good dose-dependent free radical scavenging property in all the models with the $\mathrm{IC}_{50}$ values of $98 \mu \mathrm{g} / \mathrm{mL}, 125 \mu \mathrm{g} / \mathrm{mL}$, and $96 \mu \mathrm{g} / \mathrm{mL}$ for ethanol extract and $10 \mu \mathrm{g} / \mathrm{mL}, 12 \mu \mathrm{g} / \mathrm{mL}$, and $10 \mu \mathrm{g} / \mathrm{mL}$ for flavonoid fraction, respectively. The flavonoid fraction possess potent anticancer property against breast cancer cells (MCF7) with $\mathrm{IC}_{50}$ value of $40 \mu \mathrm{g} / \mathrm{mL}$. Conclusions. It can be concluded that the aerial part of Cissus quadrangularis has potential antioxidant and anticancer activities.
\end{abstract}

\section{Introduction}

Cancer is a multistep disease incorporating physical, environmental, metabolic, chemical, and genetic factors, which play a direct and/or indirect role in the induction and deterioration of cancers. Cancer is a major public health burden in both developed and developing countries. It was estimated that 12.7 million new cancer cases and 7.6 million cancer deaths occur in 2008 [1]. The limited success of clinical therapies including radiation, chemotherapy, immunomodulation, and surgery in treating cancer, as evident by the high morbidity and mortality rates, indicates that there is an imperative need of new cancer management [2]. Drug discovery from medicinal plants has played an important role in the treatment of cancer and, indeed, most new clinical applications of plant secondary metabolites and their derivatives over the last half century have been applied towards combating cancer [3]. The National Cancer Institute collected about 35,000 plant samples from 20 countries and has screened around 114,000 extracts for anticancer activity. It was estimated that 14 cancer drugs of the top 35 drugs in year 2000 based on worldwide sales were natural products and natural product derivatives [4]. Thus, it is urgent to find more and more safe new compounds that kill cancer cells.

It is well known that many polyphenolic compounds, such as phenolic acids, flavonoids, anthocyanidins, and tannins, which possess remarkable antioxidant and anticancer activities, are rich in plant materials. Some studies have shown the positive correlation of the increased dietary intake of natural antioxidants with the reduced coronary heart disease and cancer mortality, as well as with longer life expectancy $[5,6]$. Many dietary polyphenolic constituents derived from the plants or plant extracts exhibited comparatively high antioxidant properties than the standard antioxidants, vitamins $\mathrm{E}$ or $\mathrm{C}$ by in vitro. Diet containing antioxidant rich fruits and vegetables significantly reduces the risk of many cancer diseases suggesting that antioxidants could be effective agents for the inhibition of cancer spread [7]. 
The plant Cissus quadrangularis Linn. belongs to the family Vitaceae commonly known as Pirandai, in Tamil. It is probably native to India or Sri Lanka, but also found in Africa, Arabia, and southeast Asia. The plant is used in the treatment of anorexia, dyspepsia, colic, flatulence, tumours, convulsions, asthma, epistaxis, otorrhoea, irregular menstruations, inflammations, pain, and syphilitic infections [8]. In recent years, researches about anticarcinogenic potential of quercetin have exhibited its promise as an anticancer agent. Likewise, in vitro and in vivo studies showed that quercetin was able to inhibit viability of leukemic cells, colon, and ovarian carcinoma cells, especially human breast cancer cells. In this study, we aimed to explore antioxidant potential and anticancer activity of ethanol extract and flavonoid fraction from the aerial parts of Cissus quadrangularis.

\section{Materials and Methods}

2.1. Plant Material. Cissus quadrangularis Linn. (Vitaceae) is distributed widely in India and Sri Lanka. The plant specimen for the proposed study was collected in Kancheepuram district, Tamilnadu. It was identified and authenticated by Dr. P. Jayaraman, Director Plant Anatomy Research Centre (PARC), Tambaram, Chennai. A voucher specimen of the number PARC/2012/1299 has been deposited for further references.

2.2. Preparation of Plant Extract. The powdered aerial part of Cissus quadrangularis plant was defatted with petroleum ether (b.p. 40-60 $(1: 1 \mathrm{v} / \mathrm{v}))$ in a Soxhlet apparatus. The defatted powder was macerated with ethyl alcohol (70\%) using Soxhlet until exhaustion for $72 \mathrm{~h}$ to obtain alcoholic extract. This extract was concentrated by evaporation under reduced pressure using rotavapore apparatus at $50^{\circ} \mathrm{C}$.

2.3. Phytochemical Screening. Concentrated ethanol (70\% $v / v$ ) extract was screened for the presence of various phytoconstituents using standard procedure [9].

2.4. TLC. To support preliminary chemical analysis, ethanolic extract was subjected to TLC studies. A number of developing solvent systems were tried, but the satisfactory resolution was obtained in the mobile phase Benzene: Methanol: Ammonia $(9: 1: 0.1)$ and silica gel $F$ as stationary phase. After developing, the plate was air dried and exposed to ammonia vapour, a detector specific for flavonoids.

2.5. Determination of Total Phenolic Content. The content of total phenolics in the powdered aerial part of Cissus quadrangularis was determined by using Folin-Denis reagent. About 1 gram of the powder was extracted in an ultrasonic wave bath with $80 \mathrm{~mL}$ of aqueous ethanol solution $(70 \% v / v)$ for $2 \mathrm{hr}$. After cooling, the volume of the solution was adjusted to $100 \mathrm{~mL}$. The final solution was centrifuged prior to the colorimetric determination. Tannic acid standards (10-110 mg/ $\mathrm{mL}$ ) were dissolved in $100 \mathrm{~mL}$ of aqueous ethanol solution $(70 \% v / v)$, respectively. About $10 \mathrm{~mL}$ of Folin-Denis reagent was added to $1 \mathrm{~mL}$ of the extract solution and $1 \mathrm{~mL}$ of standard solution. After reacting for $3 \mathrm{~min}, 10 \mathrm{~mL}$ of $35 \%$ sodium carbonate solution was added, and the test solution was diluted to $100 \mathrm{~mL}$ with water and mixed. After $45 \mathrm{~min}$, an aliquot was centrifuged for $5 \mathrm{~min}$. The absorption coefficient for the supernatant was measured at $745 \mathrm{~nm}$. The concentration of total phenolic compounds in the extract was determined as micrograms of Gallic acid equivalent per gram of dry matter $[10]$.

2.6. Determination of Total Flavonoids Content. The $70 \%$ ethanolic extract showed the presence of flavonoids. The total flavonoid content in the extract was determined by aluminium chloride colorimetric method, using quercetin as a standard. Five $\mathrm{mL}$ of $2 \%$ aluminium trichloride $\left(\mathrm{AlCl}_{3}\right)$ in methanol was mixed with the same volume of the extract solution $(0.4 \mathrm{mg} / \mathrm{mL})$. Absorption readings at $415 \mathrm{~nm}$ using PerkinElmer UV-VIS lambda 25 spectrophotometer were taken after 10 minutes against a blank sample consisting of a $5 \mathrm{~mL}$ extract solution with $5 \mathrm{~mL}$ ethanol without $\mathrm{AlCl}_{3}$. The total flavonoid content was determined using a standard curve with quercetin (100-1000 mg/L) as the standard. Total flavonoid content is expressed as $\mathrm{mg}$ of quercetin equivalents (Q)/g of extract [11].

2.7. Chromatographic Separation of Flavonoid Fraction. The crude alcoholic extract (10 g) was subjected to chromatography (Silica gel 120 mesh, $500 \mathrm{~g}$ ) using solvents of increasing polarity, hexane, chloroform, ethyl acetate and methanol. The collected fractions were subjected to shinoda test, followed by TLC using Benzene: Methanol: Ammonia (9:1:0.1) solvent system. The spot was visualized by spraying with ammonia, a reagent specific for flavonoids. Further the flavonoids were confirmed by TLC using the same solvent system and spraying reagent. The fractions showing positive response for flavonoid were pooled together and considered as total flavonoid fraction. The total flavonoid fraction was concentrated and subjected to further studies.

2.8. HPLC Analysis of Total Flavonoid Fraction. The HPLC analysis of the total flavonoid fraction was performed according to the method of Boligon et al. (2012) [12]. The HPLC system of Jasco consists of a pump (model Jasco PU2080, intelligent HPLC pump) with injecting facility programmed at $20 \mu \mathrm{L}$ capacity per injection was used. The detector consists of a UV/VIS (Jasco UV 2075) model operated at a wavelength of $270 \mathrm{~nm}$. The software used was Jasco Borwin version 1.5, LCNet II/ADC system. The column was Thermo ODS Hypersil $\mathrm{C} 18(250 \times 4.6 \mathrm{~mm}, 5 \mu \mathrm{m})$ in isocratic mode. The separation was achieved using a mobile phase of methanol, water, and phosphoric acid $(100: 100: 1, v / v / v)$ at a flow rate of $1.5 \mathrm{~mL} /$ min. The effluent was monitored using UV detection at a wavelength of $270 \mathrm{~nm}$. The mobile phase was filtered through $0.45 \mu \mathrm{m}$ nylon filter prior to use. Identification is based on retention times and online spectral data in comparison with authentic standards.

2.9. In Vitro Antioxidant. Several concentrations ranging from 25 to $400 \mu \mathrm{g} / \mathrm{mL}$ of the ethanolic extract and concentrations ranging from 5 to $80 \mu \mathrm{g} / \mathrm{mL}$ of total flavonoid fraction 
were tested for their antioxidant activity in different in vitro models [13]. It was observed that free radical scavenging property of the test were found to be in a concentration dependent manner in all the models.

2.10. Nitric Oxide Radical Scavenging Assay. Nitric oxide was generated from sodium nitroprusside and measured by Griess reaction. Sodium nitroprusside $(5 \mathrm{mM})$ in standard phosphate buffer saline solution $(0.025 \mathrm{M}, \mathrm{pH}$ : 7.4$)$ was incubated with different concentrations of ethanolic extract (25$400 \mu \mathrm{g} / \mathrm{mL})$ dissolved in phosphate buffer saline $(0.025 \mathrm{M}$, $\mathrm{pH}$ : 7.4), and the tubes were incubated at $25^{\circ} \mathrm{C}$ for $5 \mathrm{hr}$. Control experiments without the test compounds but equivalent amounts of buffer were conducted in an identical manner. After $5 \mathrm{hr}, 0.5 \mathrm{~mL}$ of incubation solution was removed and diluted with $0.5 \mathrm{~mL}$ of Griess reagent (1\% sulphanilamide, $2 \%$ O-phosphoric acid and $0.1 \%$ naphthyl ethylene diamine dihydrochloride). The procedure was repeated with flavonoid fraction $(5-80 \mu \mathrm{g} / \mathrm{mL})$ and quercetin as reference standard $(5-80 \mu \mathrm{g} / \mathrm{mL})$. The absorbance of the chromophore formed during diazotization of nitrite with sulphanilamide and its subsequent coupling with naphthyl ethylene diamine was read at $546 \mathrm{~nm}$. All determinations were performed in 6 replicates.

Percentage inhibition was calculated by using the following formula:

$$
\begin{aligned}
& \text { Percentage inhibition (\%) } \\
& =\frac{(\text { Absorbance of control }- \text { Absorbance of test })}{\text { Absorbance of control }} \times 100 .
\end{aligned}
$$

2.11. DPPH Radical Scavenging Activity. The free radical scavenging activity was measured in terms of hydrogen donating or radical scavenging ability, using the stable radical, DPPH. About $0.1 \mathrm{mM}$ solution of DPPH in methanol was prepared and $1 \mathrm{~mL}$ of this solution was added to $3 \mathrm{~mL}$ of the different concentration of ethanolic extract $(25-400 \mu \mathrm{g} / \mathrm{mL})$ in different test tubes. The procedure was repeated with flavonoid fraction $(5-80 \mu \mathrm{g} / \mathrm{mL})$, quercetin as reference standard $(5-80 \mu \mathrm{g} / \mathrm{mL})$, and control (without the test compound, but with an equivalent amount of methanol). The mixture was shaken and allowed to stand at room temperature for $30 \mathrm{~min}$, and the absorbance was measured at $517 \mathrm{~nm}$ using a spectrophotometer. The $\mathrm{IC}_{50}$ value $(50 \%$ of inhibitory concentration in $\mu \mathrm{g} / \mathrm{mL}$ ) of the crude extract and the isolated flavonoid fraction was compared with that of quercetin, which was used as the standard. Decrease in absorbance of the reaction mixture indicates higher free radical scavenging activity.

2.12. Hydroxyl Radical Scavenging Activity. The assay was performed by adding $0.1 \mathrm{~mL}$ EDTA, $0.01 \mathrm{~mL}$ of ferric chloride, $0.1 \mathrm{~mL}$ of hydrogen peroxide, $0.36 \mathrm{~mL}$ of deoxyribose, $1 \mathrm{~mL}$ of ethanol extract (25-400 $\mu \mathrm{g} / \mathrm{mL}), 0.33 \mathrm{~mL}$ of phosphate buffer (50 mM. pH 7.4), and $0.1 \mathrm{~mL}$ of ascorbic acid in sequence and incubated at $37^{\circ} \mathrm{C}$ for $1 \mathrm{hr}$. The procedure was repeated with flavonoid fraction $(5-80 \mu \mathrm{g} / \mathrm{mL})$, quercetin as reference standard (5-80 $\mu \mathrm{g} / \mathrm{mL}$ ), and control (without the test compound, but with an equivalent amount of methanol). A $1.0 \mathrm{~mL}$ portion of the incubated mixture was mixed with $1.0 \mathrm{~mL}$ of $10 \%$ tri chloroacetic acid and $1.0 \mathrm{~mL}$ of $0.5 \%$ thiobarbituric acid to develop the pink chromogen, which was measured at $532 \mathrm{~nm}$.

\subsection{In Vitro Anticancer Activity}

Cell Line and Culture. MCF7 cell line was obtained from National Centre for Cell Sciences, Pune (NCCS). The cells were maintained in minimal essential media supplemented with $10 \%$ FBS, penicillin $(100 \mathrm{U} / \mathrm{mL})$, and streptomycin $(100 \mu \mathrm{g} / \mathrm{mL})$ in a humidified atmosphere of $50 \mu \mathrm{g} / \mathrm{mL} \mathrm{CO}_{2}$ at $37^{\circ} \mathrm{C}$.

Reagents. MEM was purchased from Hi Media Laboratories; fetal bovine serum (FBS) was purchased from Cistron laboratories; Trypsin, methylthiazolyl diphenyl-tetrazolium bromide (MTT), and Dimethyl sulfoxide (DMSO) were purchased from Sisco research laboratory chemicals, Mumbai. All of the other chemicals and reagents were obtained from Sigma-Aldrich, Mumbai.

Procedure. Cells $\left(1 \times 10^{5} /\right.$ well $)$ were plated in $5 \mathrm{~mL}$ of medium/well in 6-well plates (Costar Corning, Rochester, NY). After 48 hours incubation, the cell reaches the confluence. Then, cells were incubated in the presence samples for $24-48 \mathrm{~h}$ at $37^{\circ} \mathrm{C}$. After removal of the sample solution and washing with phosphate-buffered saline $(\mathrm{pH} 7.4)$, $1 \mathrm{~mL} /$ well $(5 \mathrm{mg} / \mathrm{mL})$ of $0.5 \% 3$-(4,5-dimethyl-2-thiazolyl)2,5-diphenyl-tetrazolium bromide cells (MTT) phosphatebuffered saline solution was added. After $4 \mathrm{~h}$ incubation, $0.04 \mathrm{M} \mathrm{HCl} /$ isopropanol was added. Viable cells were determined by the absorbance at $570 \mathrm{~nm}$. Measurements were performed, and the concentration required for a $50 \%$ inhibition of viability $\left(\mathrm{IC}_{50}\right)$ was determined graphically. The absorbance at $570 \mathrm{~nm}$ was measured with a UV-Spectrophotometer using wells without sample containing cells as blanks [14]. The effect of the samples on the proliferation of $M C F-7$ cells was expressed as the \% cell viability, using the following formula:

$$
\% \text { cell viability }=\frac{A_{570} \text { of treated cells }}{A_{570} \text { of control cells }} \times 100 \% \text {. }
$$

\section{Results and Discussion}

3.1. Preliminary Phytochemical Screening. The ethanolic extract showed positive results for the presence of alkaloids, carbohydrates, flavonoids, saponins, and tannins.

3.2. Thin Layer Chromatography. The ethanol extract was subjected to thin layer chromatography. The number of solvent system was tried but the solvent system which shows good resolution was used. The ethanol extract showed seven spots with $R_{f}$ values of $0.16,0.25,0.33,0.41,0.50,0.53$, and 0.66 using the solvent system Benzene : Methanol : Ammonia $(9: 0.5: 0.5)$. The results were shown in Figure 1. 


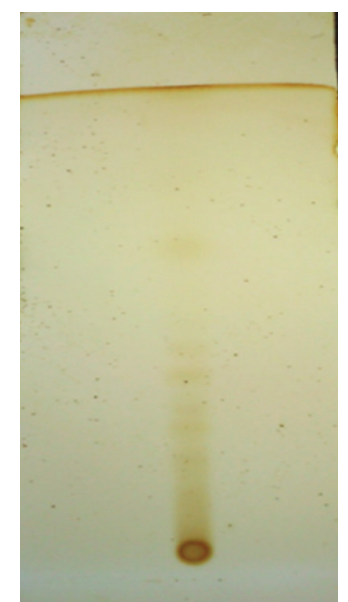

Figure 1: TLC of ethanolic extract of Cissus quadrangularis Linn.

3.3. Estimation of Phytoconstituents. Flavonoids are the most diverse and widespread group of natural compounds and are likely to be the most important natural phenolics. These compounds possess a broad spectrum of chemical and biological activities including radical scavenging activity. The contents of total phenols and flavonoids were estimated by the standard curves and expressed as gallic acid equivalents for total phenols and quercetin equivalents for flavonoids. The amount of total phenolic content and total flavonoid content in the ethanol extract showed $28.6 \mathrm{mg} / \mathrm{g}$ dry weight, expressed as Gallic acid equivalents and $15.8 \mathrm{mg} / \mathrm{g}$ expressed as quercetin equivalents, respectively.

3.4. Isolation of Flavonoid Fraction. Totally 93 fractions were eluted. Shinoda test was carried out for confirming the presence of flavonoids and TLC studies was carried out using Chloroform : ethyl acetate $(6: 4)$ and Iodine vapour as detecting agent for all the fractions. The eluates chloroform : ethyl acetate $(75: 25)$, ethyl acetate $(100 \%)$, ethyl acetate : methanol (50:50), and methanol (100) gave positive response for flavonoids producing pink colour with Shinoda test. The fractions 1-19 did not exhibit any spots. The fractions 20-25 and 33-40 exhibited spots, but flavonoids were absent. however in between the 41-64, 65-70, 76-81, and 87-93 fraction exhibited single spot with $R_{f}$ values of $0.12,0.43,0.54$, and 0.66 . Fractions with similar spots and positive test for flavonoids were pooled together and concentrated. The concentrated fractions after evaporation revealed brown crystalline powder. The results were tabulated in Table 1.

3.5. High-Performance Liquid Chromatography. The HPLC chromatograms of total flavonoid fraction from the aerial parts of Cissus quadrangularis showed 4 components (Figure 2). The main difference was in peak eluted at $3.680 \mathrm{~min}$ and $5.1 \mathrm{~min}$, respectively. In the present investigation, 2 flavonoids were quantified at $254 \mathrm{~nm}$ using peak area by comparison to a calibration curve derived from the standard, quercetin $(3.36 \% w / w)$, and rutin $(0.49 \% w / w)$ (Figure 3). The results above showed, therefore, that the aerial part of Cissus quadrangularis is a rich source of the

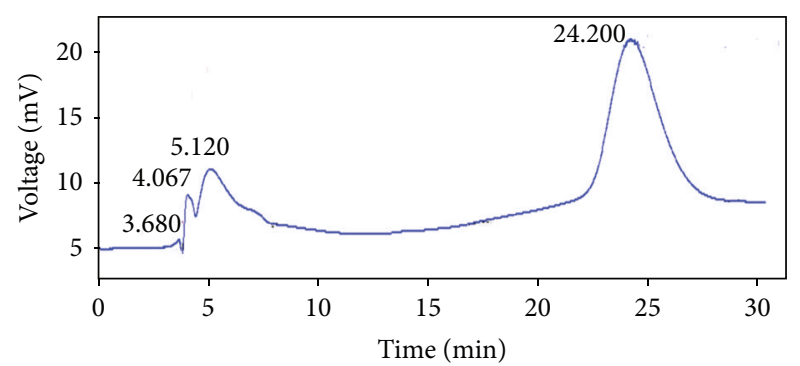

FIGURE 2: HPLC of isolated flavonoid fraction from Cissus quadrangularis Linn.

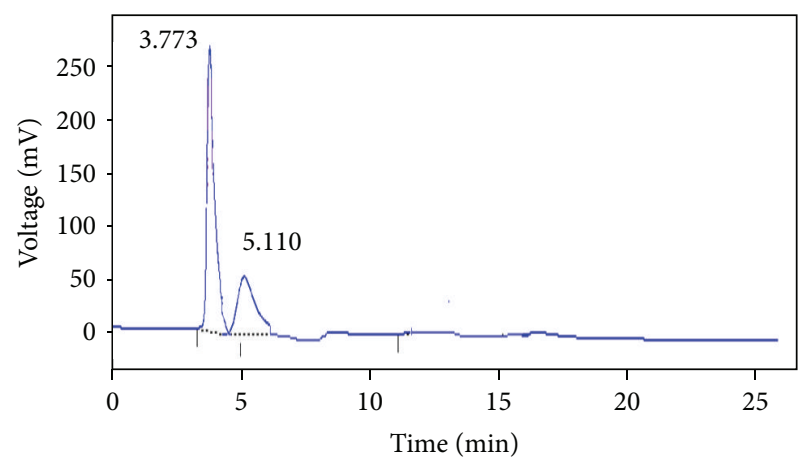

FIGURE 3: HPLC of reference standards, (1) rutin and (2) quercetin.

important biologically active flavonoids, quercetin, and rutin. The described HPLC procedure could be useful for the qualitative and quantitative analysis of flavonoids in plant materials.

3.6. Antioxidant Activity. In the human body, the free radicals are continuously produced due to the oxygen utilization by the cells of the body. This generates a series of reactive oxygen species (ROS) like super oxide anion $\left(\mathrm{O}_{2}{ }^{-}\right)$and hydroxyl $\left(\mathrm{HO}^{\circ}\right)$ radicals and nonfree radical species such as $\mathrm{H}_{2} \mathrm{O}_{2}$, singled oxygen and nitric oxide (NO). Reactive oxygen species and reactive nitrogen species are associated with many pathological conditions such as atherosclerosis, ischemia, and reperfusion injury of many tissues, central nervous system injury, gastritis, and cancer [15].

Phytocompounds like flavonoids and phenolic acids, commonly found in plants have been reported to have multiple biological and pharmacological activities including antioxidative, cytotoxic, anticancer, antimicrobial, antiviral, and anti-inflammatory activities [16]. Antioxidants cause protective effect by neutralizing free radicals, which are toxic byproducts of natural cell metabolism. The human body has several mechanisms to counteract oxidative stress by producing antioxidants, which are either naturally produced in situ or externally supplied through foods and/or supplements. These antioxidants act as free radical scavengers by preventing and repairing damages caused by ROS and therefore can enhance the immune defense and lower the risk of cancer and degenerative diseases [17]. 
TABLE 1: Isolation of total flavonoid fraction from the ethanol extract of Cissus quadrangularis.

\begin{tabular}{|c|c|c|c|c|c|}
\hline S. no & Fraction & Eluates & TLC & $R_{f}$ value & Nature of the compound \\
\hline 1 & $1-5$ & Hexane (100) & No distinct spot & - & - \\
\hline 2 & $5-10$ & $\begin{array}{l}\text { Hexane: chloroform } \\
\qquad(75: 25)\end{array}$ & No distinct spot & - & - \\
\hline 3 & $11-14$ & $\begin{array}{l}\text { Hexane: chloroform } \\
\qquad(50: 50)\end{array}$ & No distinct spot & - & - \\
\hline 4 & $15-19$ & $\begin{array}{l}\text { Hexane : chloroform } \\
\qquad(25: 75)\end{array}$ & No distinct spot & - & - \\
\hline 5 & $20-25$ & Chloroform (100) & Single spot & 0.09 & Negative for flavonoid test \\
\hline 6 & $26-32$ & $\begin{array}{l}\text { Chloroform : ethyl acetate } \\
\qquad(75: 25)\end{array}$ & No distinct spot & - & - \\
\hline 7 & $33-40$ & $\begin{array}{l}\text { Chloroform : ethyl acetate } \\
\qquad(50: 50)\end{array}$ & Single spot & 0.11 & Negative for flavonoid test \\
\hline 8 & $41-64$ & $\begin{array}{l}\text { Chloroform : ethyl acetate } \\
\qquad(25: 75)\end{array}$ & Single spot & 0.12 & $\begin{array}{l}\text { Positive for flavonoid test yellowish } \\
\text { amorphous powder }\end{array}$ \\
\hline 9 & $65-70$ & Ethyl acetate (100\%) & Single spot & 0.43 & $\begin{array}{l}\text { Positive for flavonoid test yellowish } \\
\text { brown amorphous powder }\end{array}$ \\
\hline 10 & $71-75$ & $\begin{array}{l}\text { Ethyl acetate : methanol } \\
\qquad(75: 25)\end{array}$ & No distinct spot & - & - \\
\hline 11 & $76-81$ & $\begin{array}{l}\text { Ethyl acetate : methanol } \\
\qquad(50: 50)\end{array}$ & Single spot & 0.54 & $\begin{array}{l}\text { Positive for flavonoid test brown sticky } \\
\text { residue }\end{array}$ \\
\hline 12 & $82-86$ & $\begin{array}{l}\text { Ethyl acetate: methanol } \\
\qquad(25: 75)\end{array}$ & No distinct spot & - & Brown sticky residue \\
\hline 13 & $87-93$ & Methanol (100\%) & Single spot & 0.66 & $\begin{array}{l}\text { Positive for flavonoid test brown sticky } \\
\text { residue }\end{array}$ \\
\hline
\end{tabular}

TABLE 2: Free radicals scavenging property of ethanolic extract and isolated flavonoid fraction of Cissus quadrangularis Linn.

\begin{tabular}{|c|c|c|c|c|}
\hline Test & Concentration $(\mu \mathrm{g} / \mathrm{mL})$ & Nitric oxide inhibition (\%) & $\begin{array}{c}\text { DPPH radical inhibition } \\
(\%)\end{array}$ & $\begin{array}{c}\text { Hydroxyl radical inhibition } \\
(\%)\end{array}$ \\
\hline \multirow{6}{*}{ Ethanol extract } & 25 & $34.15 \pm 1.26^{* *}$ & $27.67 \pm 1.17^{* *}$ & $36.57 \pm 0.54^{* *}$ \\
\hline & 50 & $48.18 \pm 0.36^{* *}$ & $38.05 \pm .25^{* *}$ & $48.16 \pm 1.40^{* *}$ \\
\hline & 100 & $51.84 \pm 2.72^{* *}$ & $43.63 \pm .58^{* *}$ & $53.32 \pm 1.08^{* *}$ \\
\hline & 200 & $69.24 \pm 1.96^{* *}$ & $61.80 \pm 2.43^{* *}$ & $63.21 \pm 1.72^{* *}$ \\
\hline & 400 & $74.32 \pm 2.16^{* *}$ & $73.67 \pm 0.35^{* *}$ & $78.96 \pm 0.61^{* *}$ \\
\hline & $\mathrm{IC}_{50}$ & $98 \mu \mathrm{g} / \mathrm{mL}$ & $125 \mu \mathrm{g} / \mathrm{mL}$ & $96 \mu \mathrm{g} / \mathrm{mL}$ \\
\hline \multirow{6}{*}{ Flavonoid fraction } & 5 & $32.58 \pm 0.58^{* *}$ & $28.05 \pm 1.20^{* *}$ & $35.45 \pm 1.20^{* *}$ \\
\hline & 10 & $50.24 \pm 3.28^{* *}$ & $45.23 \pm 2.18^{* *}$ & $50.32 \pm 1.50^{* *}$ \\
\hline & 20 & $67.38 \pm 0.54^{* *}$ & $64.80 \pm 1.43^{* *}$ & $62.24 \pm 3.28^{* *}$ \\
\hline & 40 & $72.26 \pm 0.86^{* *}$ & $73.67 \pm 2.85^{* *}$ & $69.38 \pm 0.54^{* *}$ \\
\hline & 80 & $82.89 \pm 0.97^{* *}$ & $80.89 \pm 1.40^{* *}$ & $79.26 \pm 0.86^{* *}$ \\
\hline & $\mathrm{IC}_{50}$ & $10 \mu \mathrm{g} / \mathrm{mL}$ & $12 \mu \mathrm{g} / \mathrm{mL}$ & $10 \mu \mathrm{g} / \mathrm{mL}$ \\
\hline \multirow{6}{*}{ Standard quercetin } & 5 & $28.30 \pm 1.08^{* *}$ & $30.25 \pm 0.47^{* *}$ & $34.25 \pm 0.47^{* *}$ \\
\hline & 10 & $35.25 \pm 0.47^{* *}$ & $41.10 \pm 2.16^{* *}$ & $42.10 \pm 3.16^{* *}$ \\
\hline & 20 & $44.10 \pm 2.16^{* *}$ & $49.66 \pm 1.12^{* *}$ & $48.66 \pm 1.12^{* *}$ \\
\hline & 40 & $56.66 \pm 1.12^{* *}$ & $67.09 \pm 0.16^{* *}$ & $62.29 \pm 0.54^{* *}$ \\
\hline & 80 & $71.79 \pm 0.54^{* *}$ & $75.25 \pm 2.47^{* *}$ & $73.25 \pm 0.47^{* *}$ \\
\hline & $\mathrm{IC}_{50}$ & $35 \mu \mathrm{g} / \mathrm{mL}$ & $25 \mu \mathrm{g} / \mathrm{mL}$ & $32 \mu \mathrm{g} / \mathrm{mL}$ \\
\hline
\end{tabular}

Values are mean \pm SEM, statistical significant test for comparison was done by ANOVA, followed by Dunnet's $t$-test $(n=6)$. The values are ${ }^{* *} P<0.01$ when compared against standard. 


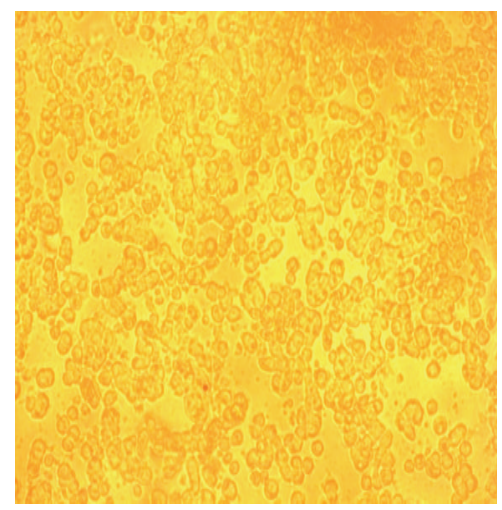

Normal MCF-7 cell line

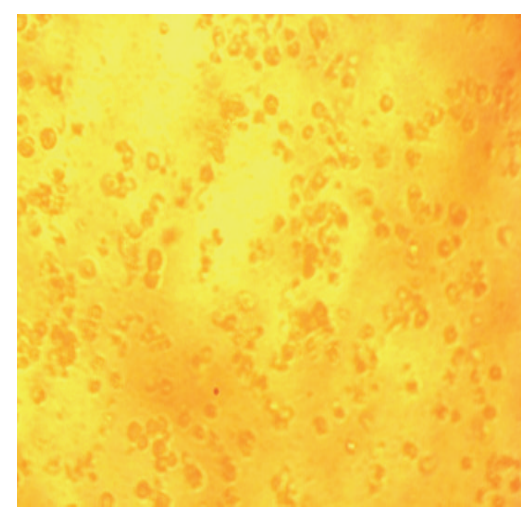

Toxicity- $160 \mu \mathrm{g} / \mathrm{mL}$

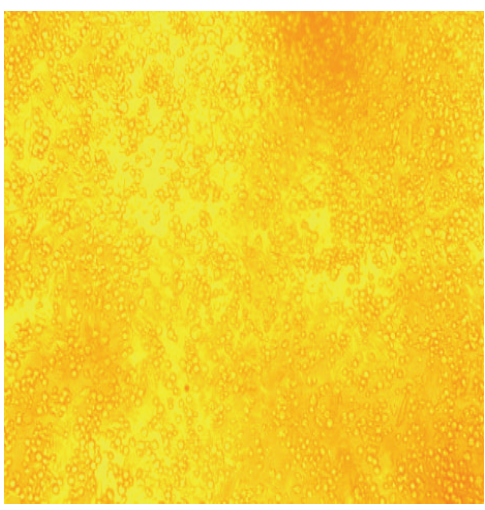

Toxicity $-80 \mu \mathrm{g} / \mathrm{mL}$

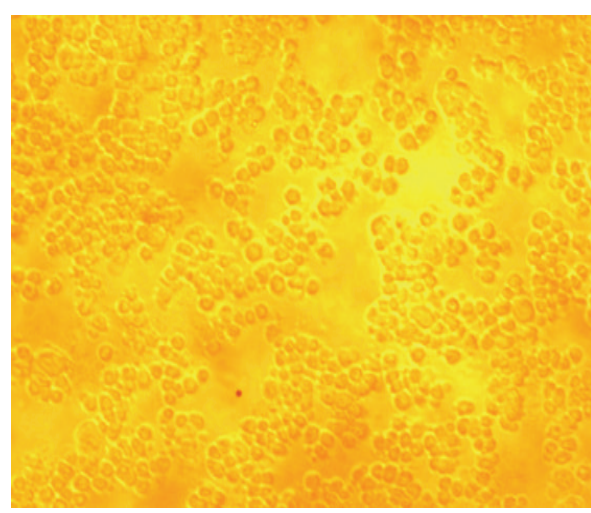

Toxicity $-40 \mu \mathrm{g} / \mathrm{mL}$

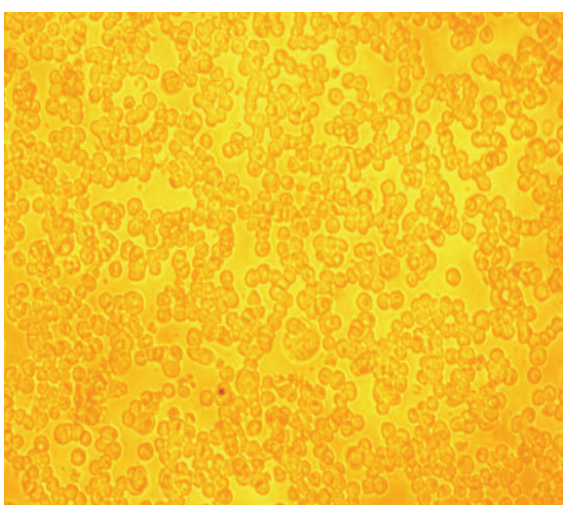

Toxicity $-20 \mu \mathrm{g} / \mathrm{mL}$

FIgURE 4: Anticancer effect of 70\% ethanolic extract of Cissus quadrangularis on MCF-7 cell line at different concentrations.

Several concentrations ranging from 25 to $400 \mu \mathrm{g} / \mathrm{mL}$ of the ethanolic extract and 5 to $80 \mu \mathrm{g} / \mathrm{mL}$ of the flavonoid fraction were tested for their antioxidant activity in different in vitro models. It was observed that free radical scavenging property of the test were found to be in a concentration dependent manner in all the models. The results were shown in Table 2.

3.6.1. Nitric Oxide Scavenging Activity. The scavenging of nitric oxide by ethanolic extract $(25-400 \mu \mathrm{g} / \mathrm{mL})$ and flavonoid fraction and quercetin as reference standard (5$80 \mu \mathrm{g} / \mathrm{mL}$ ) were concentration dependent. The $\mathrm{IC}_{50}$ values of ethanolic extract, flavonoid fraction, and standard quercetin were found to be $98 \mu \mathrm{g} / \mathrm{mL}, 10 \mu \mathrm{g} / \mathrm{mL}$, and $35 \mu \mathrm{g} / \mathrm{mL}$, respectively. On a comparative basis, the flavonoid fraction showed better activity in quenching nitric oxide with an $\mathrm{IC}_{50}$ value of $10 \mu \mathrm{g} / \mathrm{mL}$.

Nitric oxide (NO) is a free radical produced in mammalian cells, involved in the regulation of various physiological processes. However, excess production of $\mathrm{NO}$ is associated with several diseases. Nitric oxide is a very unstable species under aerobic conditions. It reacts with $\mathrm{O}^{2}$ to produce stable product nitrate and nitrite through intermediates $\mathrm{NO}_{2}$, $\mathrm{N}_{2} \mathrm{O}_{4}$, and $\mathrm{N}_{3} \mathrm{O}_{4}$. It is estimated by using Griess reagent and in presence of test compound which is a scavenger that the amount of nitrous acid will decrease [13]. In the present study, the nitrite produced by the incubation of solutions of sodium nitroprusside in standard phosphate saline buffer at $25^{\circ} \mathrm{C}$ was reduced by the ethanol extract and flavonoid fraction. Significant scavenging activity was observed for ethanol extract and flavonoid fraction. This may be due to the antioxidant principles of flavonoid, which compete with oxygen to react with nitric oxide, leading to reduced production of nitric oxide.

3.6.2. Inhibition of DPPH Radical. The potential decrease in the concentration of DPPH radical due to the scavenging ability of ethanolic extract and flavonoid fraction showed significant free radical, scavenging activity of about $73 \%$ and $80 \%$, respectively, at higher doses with the $\mathrm{IC}_{50}$ value being $125 \mu \mathrm{g} / \mathrm{mL}$ and $12 \mu \mathrm{g} / \mathrm{mL}$, respectively.

DPPH assay is considered a valid and easy way to evaluate scavenging activity of antioxidants, since the radical compound is stable and does not have to generated as in other radical assays. DPPH radicals react with suitable reducing agents and then electrons become paired off, and the solution loses colour with the number of electrons taken up. Such reactivity has been widely used to test the ability of compound and plant extract to act as free radical scavengers. Reduction of the DPPH radicals can be observed by the decrease in absorbance at $517 \mathrm{~nm}$. Thus, an antioxidant candidate which 


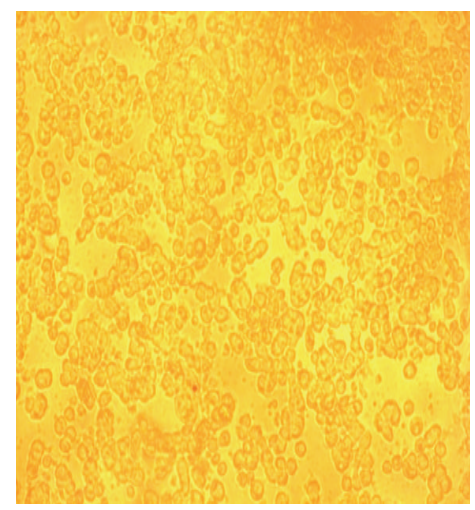

Normal MCF-7 cell line

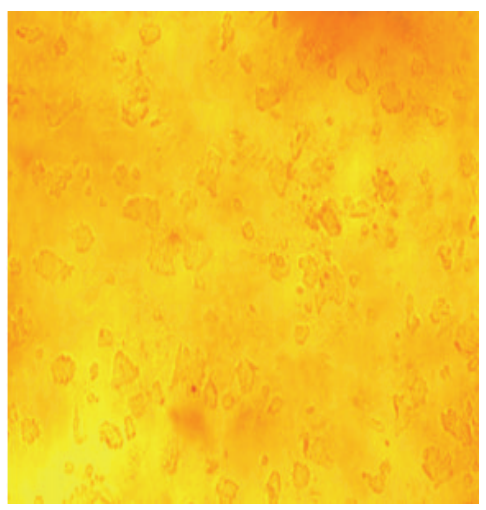

Toxicity $-80 \mu \mathrm{g} / \mathrm{mL}$

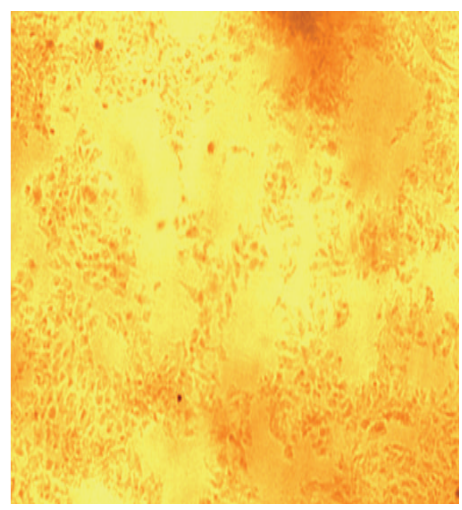

Toxicity-40 $\mu \mathrm{g} / \mathrm{mL}$

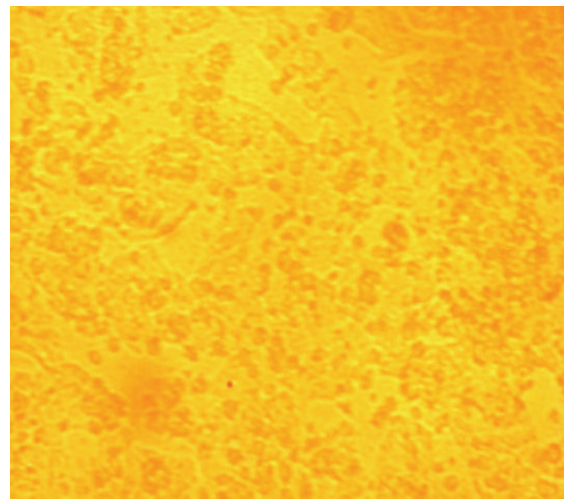

Toxicity $-20 \mu \mathrm{g} / \mathrm{mL}$

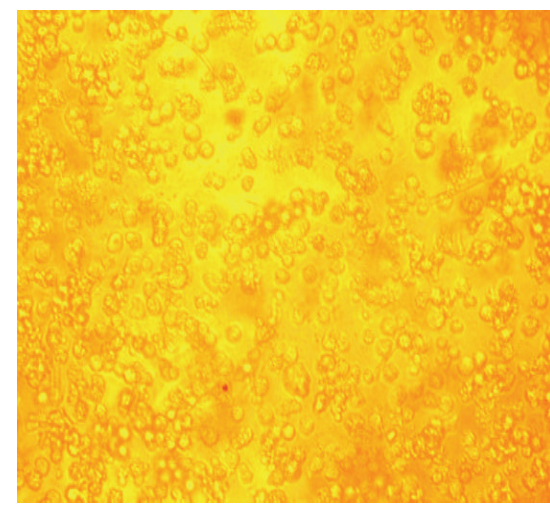

Toxicity $-10 \mu \mathrm{g} / \mathrm{mL}$

FIGURE 5: Anticancer effect of flavonoid fraction of Cissus quadrangularis on MCF-7 cell line at different concentrations.

proves promising in the DPPH antioxidant assay would provide an optimistic scaffold for prospective in vivo studies [18]. Prasad et al. [19] reported that phenolics and flavonoids reduce the DPPH radicals by their hydrogen donating ability. The $\mathrm{IC}_{50}$ value of the flavonoid fraction was more compared with that of the total extract. Hence flavonoid fraction has more antioxidant activity.

Inhibition of Hydroxyl Radical. The potentially reactive hydroxyl radicals can cause oxidative damage to DNA, lipids and proteins. The effect of ethanolic extract and flavonoid fraction on the inhibition of free radical-mediated deoxyribose damage was assessed by means of iron (II)-dependent DNA damage assay, which showed significant results. The IC $_{50}$ values were $96 \mu \mathrm{g} / \mathrm{mL}$ and $10 \mu \mathrm{g} / \mathrm{mL}$ respectively.

3.7. In Vitro Anticancer Activity. In order to understand the effect of ethanol extract and isolated flavonoid fraction of Cissus quadrangularis on human breast cancer cells, experiments were conducted using cultured MCF7 cell lines. MTT assay is a well-established in vitro method for assessing cytotoxicity against cancer cell lines. Results of the cell viability were measured using MTT assay (Figures 4 and 5). With ethanol extract and isolated flavonoid fraction at all concentrations $(0.625-160 \mu \mathrm{g} / \mathrm{mL})$ for 24 hour reduced the viability of these cells. The dead cells were increased by increasing the concentration of both ethanol extract and isolated flavonoid fraction (Table 3). The lowest MCF7 cell viability (11.27\%) was recorded by flavonoid fraction for concentration of $80 \mu \mathrm{g} / \mathrm{mL}$, while it was $15.8 \%$ for $160 \mu \mathrm{g} / \mathrm{mL}$ concentration of ethanol extract. The $\mathrm{IC}_{50}$ values were determined from the graphs of the ethanol extract and isolated flavonoid fraction on MCF7 cell lines. Isolated flavonoid fraction showed potent cytotoxic effects with the $\mathrm{IC}_{50}$ values of $10 \mu \mathrm{g} / \mathrm{mL}$ in MCF7 cell line whereas ethanol extract gave the $\mathrm{IC}_{50}$ values of $40 \mu \mathrm{g} / \mathrm{mL}$ in MCF7 cell line. According to the National Cancer Institute (NCI), the criteria of cytotoxic activity for the crude extract are $\mathrm{IC}_{50}<20 \mu \mathrm{g} / \mathrm{mL}$ [20]. The $\mathrm{IC}_{50}$ values indicated that the anticancer activity of isolated flavonoid fraction was higher than ethanol extract against MCF7 cell lines (Figures 4 and 5 ), and the $\mathrm{IC}_{50}$ of the isolated flavonoid fraction fall within the NCI criteria, thus the flavonoid fraction are considered as promising anticancer potential.

Flavonoids are among the best candidates for mediating the protective effect of diets which are found in fruits and vegetables with respect to colorectal cancer. Study shows relative activity being as quercetin $>$ apigenin $>$ fisetin $>$ kaempferol. Quercetin belongs to the flavonoids group due to its powerful antioxidant activity. Previous studies showed that quercetin may help to prevent cancer, especially prostate cancer. Scambia et al. reported quercetin inhibited human breast cancer cells (MCF-7 and MDA-MB231) significantly [21]. Du et al. explained mechanism of breast cancer inhibition by quercetin [22]. Antioxidant activity of quercetin was believed 
TABLE 3: Anticancer effect of ethanolic extract and flavonoid fraction on MCF7 cell line.

\begin{tabular}{|c|c|c|c|c|c|}
\hline \multirow{2}{*}{ S. no } & \multirow{2}{*}{ Concentration $(\mu \mathrm{g} / \mathrm{mL})$} & \multicolumn{2}{|c|}{ Ethanolic extract } & \multicolumn{2}{|c|}{ Flavonoid fraction } \\
\hline & & Absorbance (O.D) & Cell viability (\%) & Absorbance (O.D) & Cell viability (\%) \\
\hline 1 & 160 & 0.10 & 15.8 & 0.07 & 11.1 \\
\hline 2 & 80 & 0.21 & 33.3 & 0.13 & 20.6 \\
\hline 3 & 40 & 0.32 & 50.7 & 0.22 & 34.9 \\
\hline 4 & 20 & 0.40 & 63.4 & 0.31 & 50.3 \\
\hline 5 & 10 & 0.49 & 77.7 & 0.39 & 61.9 \\
\hline 6 & 5 & 0.52 & 82.5 & 0.46 & 73.0 \\
\hline 7 & 2.5 & 0.54 & 85.7 & 0.52 & 82.5 \\
\hline 8 & 1.25 & 0.58 & 92.0 & 0.57 & 90.4 \\
\hline 9 & 0.625 & 0.60 & 95.2 & 0.63 & 100 \\
\hline 10 & Cell control & 0.63 & 100 & 0.07 & 11.1 \\
\hline
\end{tabular}

to have cytoprotective role against oxidative stress. It seemed that quercetin not only protects cells from free radical damage through antioxidant effect, but also motivates apoptotic cell death via pro-oxidant activity and inhibits tumourigenesis [23]. Hence, anticancer power may be related to quercetin content in those varieties. In addition, flavonoid compounds could probably be responsible for the anticancer activity of Cissus quadrangularis.

\section{Conclusion}

Traditional Indian and Chinese medicinal herbs have been used in the treatment of different diseases in the country for centuries. There have been claims that some traditional healers can successfully treat cancer using herbal drugs. In this study, it is evident that the ethanol extracts and isolated flavonoid fraction of Cissus quadrangularis Linn. possess effective antioxidant and anticancer activities. This is due to the presence of phytochemicals like flavonoids such as quercetin and rutin.

\section{References}

[1] J. Ferlay, H. R. Shin, F. Bray, D. Forman, C. Mathers, and D. M. Parkin, "Estimates of worldwide burden of cancer in 2008: GLOBOCAN 2008," International Journal of Cancer, vol. 127, no. 12, pp. 2893-2917, 2010.

[2] J. Dai and R. J. Mumper, "Plant phenolics: extraction, analysis and their antioxidant and anticancer properties," Molecules, vol. 15, no. 10, pp. 7313-7352, 2010.

[3] M. J. Balunas and A. D. Kinghorn, "Drug discovery from medicinal plants," Life Sciences, vol. 78, no. 5, pp. 431-441, 2005.

[4] M. Shoeb, "Anticancer agents from medicinal plants," Bangladesh Journal of Pharmacology, vol. 1, no. 2, pp. 35-41, 2006.

[5] M. Namiki, "Antioxidants/antimutagens in food," Critical Reviews in Food Science and Nutrition, vol. 29, no. 4, pp. 273300, 1990.

[6] K. Nagendra Prasad, H. Xie, J. Hao et al., "Antioxidant and anticancer activities of 8-hydroxypsoralen isolated from wampee [Clausena lansium (Lour.) Skeels] peel," Food Chemistry, vol. 118, no. 1, pp. 62-66, 2010.

[7] P. Fresco, F. Borges, C. Diniz, and M. P. M. Marques, "New insights on the anticancer properties of dietary polyphenols," Medicinal Research Reviews, vol. 26, no. 6, pp. 747-766, 2006.
[8] A. Chatterjee and S. Chandraprakash, The Treatise of Indian Medicinal Plants, vol. 3 of Publications and Information Directorate, CSIR, New Delhi, India, 1997.

[9] C. K. Kokate, Practical Pharmacognosy, Vallabh Prakashan, Delhi, India, 4th edition, 1994.

[10] Y.-C. Liu, J.-G. Zeng, B. Chen, and S.-Z. Yao, "Investigation of phenolic constituents in Echinacea purpurea grown in China," Planta Medica, vol. 73, no. 15, pp. 1600-1605, 2007.

[11] T. K. Panovska, S. Kulevanova, and M. Stefova, "In vitro antioxidant activity of some Teucrium species (Lamiaceae)," Acta Pharmaceutica, vol. 55, no. 2, pp. 207-214, 2005.

[12] A. A. Boligon, T. F. de Brum, J. K. Frolhich, A. L. F. Froeder, and M. L. Athayde, "HPLC/DAD profile and determination of total phenolics, flavonoids, tannins and alkaloids contents of Scutia buxifolia reissek stem bark," Research Journal of Phytochemistry, vol. 6, no. 3, pp. 84-91, 2012.

[13] A. Shirwaikar, K. S. Prabhu, and I. S. R. Punitha, "In vitro antioxidant studies of Sphaeranthus indicus (Linn)," Indian Journal of Experimental Biology, vol. 44, no. 12, pp. 993-996, 2006.

[14] K. N. Prasad, G. Ashok, C. Raghu, G. R. Shivamurthy, P. Vijayan, and S. M. Aradhya, "In vitro cytotoxic properties of Ipomoea aquatica leaf," Indian Journal of Pharmacology, vol. 37, no. 6, pp. 397-398, 2005.

[15] S. Manoharan, K. Kolanjiappan, K. Suresh, and K. Panjamurthy, "Lipid peroxidation \& antioxidants status in patients with oral squamous cell carcinoma," Indian Journal of Medical Research, vol. 122, no. 6, pp. 529-534, 2005.

[16] E. Middleton Jr., C. Kandaswami, and T. C. Theoharides, "The effects of plant flavonoids on mammalian cells: implications for inflammation, heart disease, and cancer," Pharmacological Reviews, vol. 52, no. 4, pp. 673-751, 2000.

[17] B. Kumar, H. K. Sandhar, S. Prasher, P. Tiwari, M. Salhan, and P. Sharma, "A review of phytochemistry and pharmacology of flavonoids," Internationale Pharmaceutica Sciencia, vol. 1, no. 1, pp. 25-41, 2011.

[18] S. Ganapaty, V. M. Chandrashekhar, H. R. Chitme, and M. Lakashmi Narsu, "Free radical scavenging activity of gossypin and nevadensin: an in-vitro evaluation," Indian Journal of Pharmacology, vol. 39, no. 6, pp. 281-283, 2007.

[19] K. N. Prasad, S. Divakar, G. R. Shivamurthy, and S. M. Aradhya, "Isolation of a free radical-scavenging antioxidant from water spinach (Ipomoea aquatica Forsk)," Journal of the Science of Food and Agriculture, vol. 85, no. 9, pp. 1461-1468, 2005.

[20] J. Boik, Natural Compounds in Cancer Therapy, Oregon Medical Press, Minnesota, Minn, USA, 2001. 
[21] G. Scambia, F. O. Ranelletti, P. B. Panici et al., "Quercetin potentiates the effect of adriamycin in a multidrug-resistant MCF-7 human breast-cancer cell line: P-glycoprotein as a possible target," Cancer Chemotherapy and Pharmacology, vol. 34, no. 6, pp. 459-464, 1994.

[22] G. Du, H. Lin, M. Wang et al., "Quercetin greatly improved therapeutic index of doxorubicin against $4 \mathrm{~T} 1$ breast cancer by its opposing effects on HIF-1 $\alpha$ in tumor and normal cells," Cancer Chemotherapy and Pharmacology, vol. 65, no. 2, pp. 277-287, 2010.

[23] L. Gibellini, M. Pinti, M. Nasi et al., "Interfering with ROS metabolism in cancer cells: the potential role of quercetin," Cancers, vol. 2, no. 2, pp. 1288-1311, 2010. 

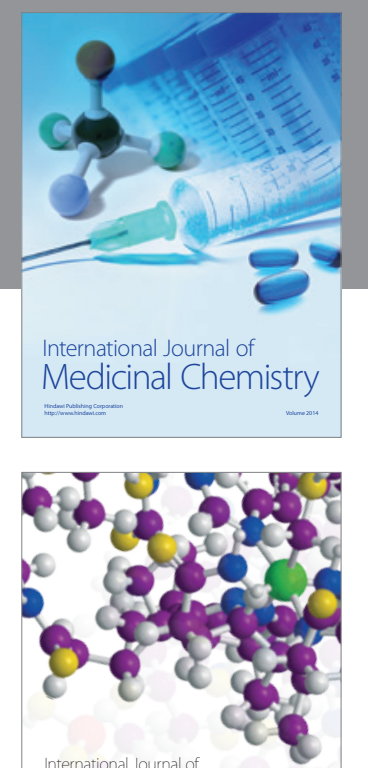

\section{Carbohydrate} Chemistry

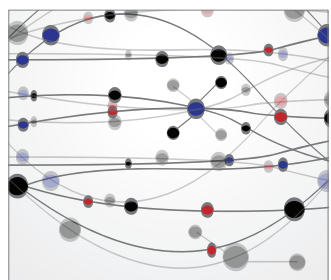

The Scientific World Journal
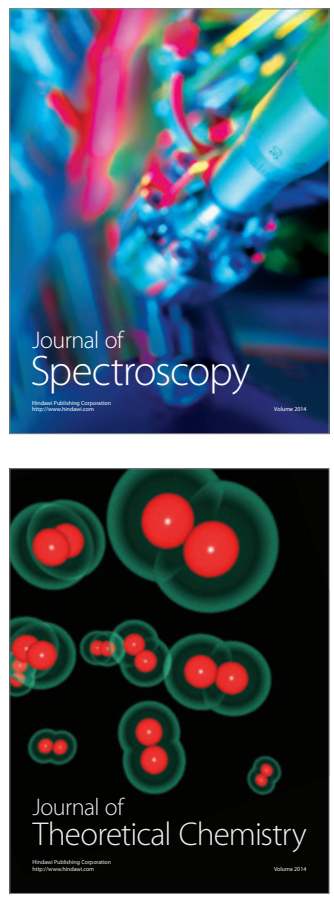
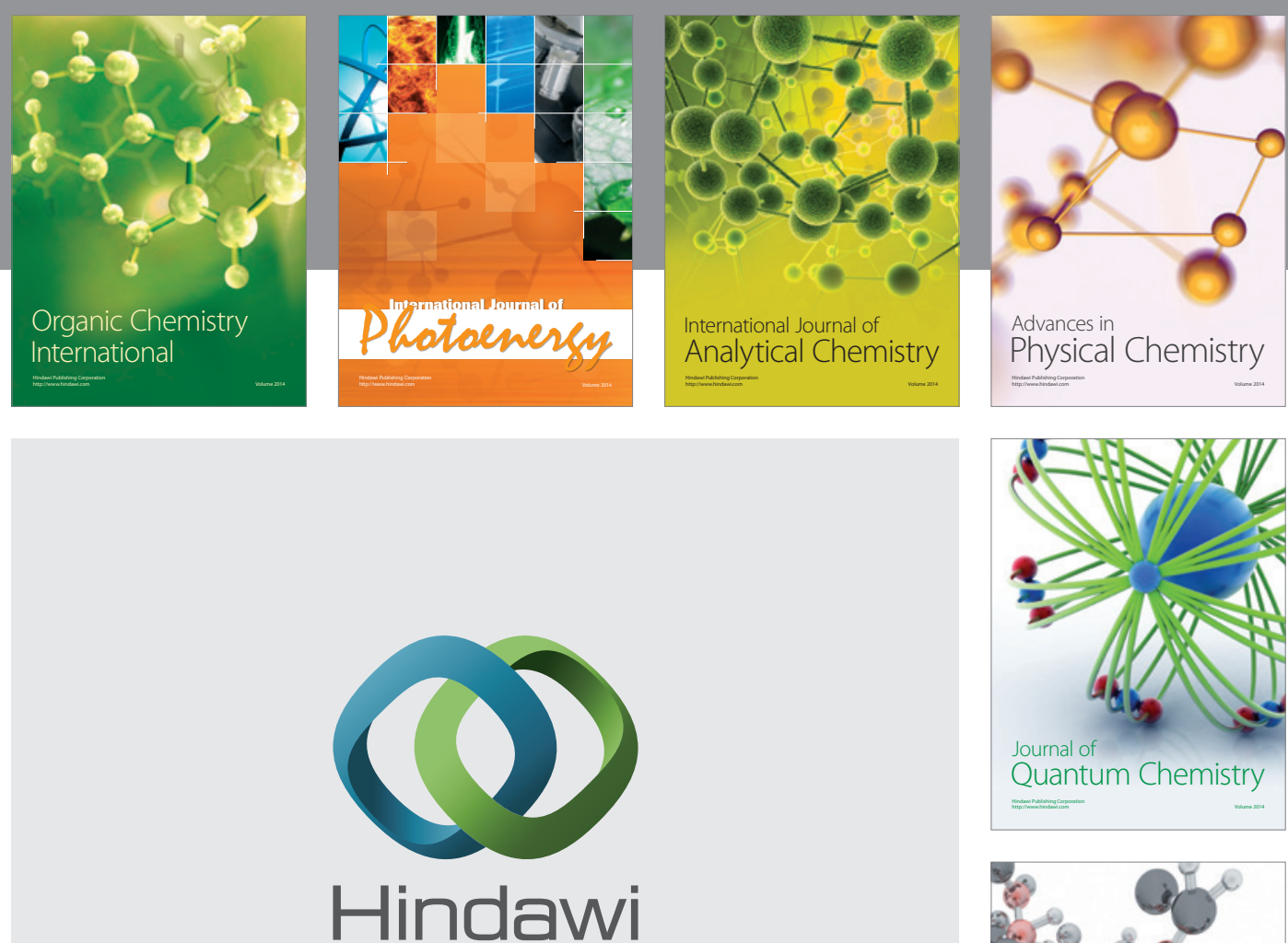

Submit your manuscripts at

http://www.hindawi.com

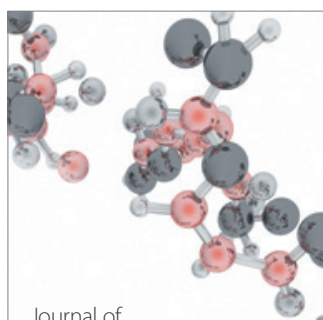

Analytical Methods

in Chemistry

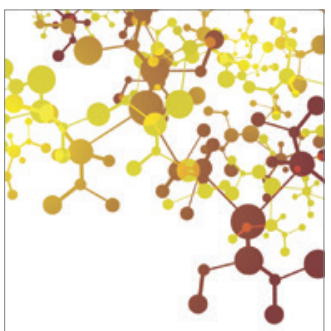

Journal of

Applied Chemistry

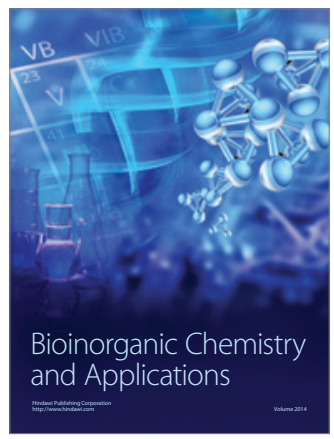

Inorganic Chemistry
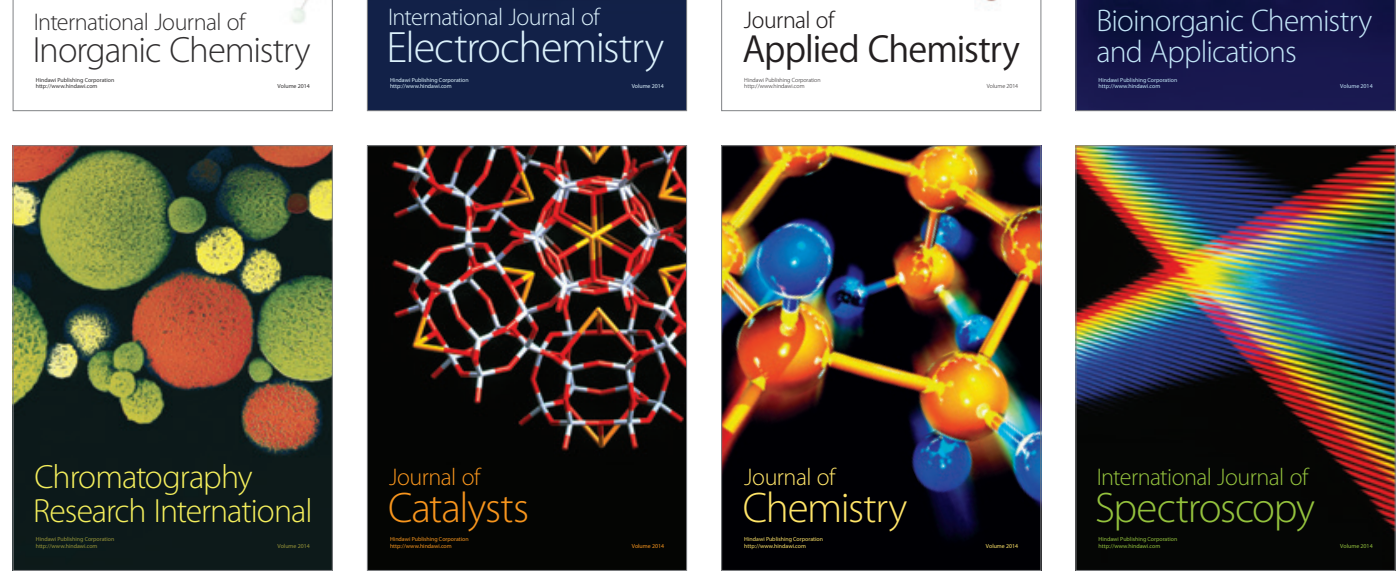